\title{
APPLYING THE INQUA SCALE TO THE SOFADES 1954, CENTRAL GREECE, EARTHQUAKE
}

\author{
Papathanassiou G. ${ }^{1}$, Valkaniotis S. ${ }^{1,2}$, and Pavlides S. ${ }^{1}$ \\ ${ }^{l}$ Aristotle University of Thessaloniki, Faculty of Sciences, Department of Geology, \\ gpapatha@geo.auth.gr,svalkan@geo.auth.gr,pavlides@geo.auth.gr \\ ${ }^{2}$ National Observatory of Athens, Geodynamic Institute
}

\begin{abstract}
Macroseismic intensity scales are used in order to measure the size of an earthquake using the impact of the ground shaking on humans, man made environment and nature. The INQUA scale is a new scale based solely on the earthquake-induced ground deformations, proposed by the INQUA Subcommission on Paleoseismicity. This scale is applied to the Sofades 1954 earthquake in order to test its accuracy and reliability. From the comparison among the evaluated intensities based on MM scale with the degrees of INQUA intensity at several locations, we conclude that, in case of earthquakes which triggered remarkable geological effects, these intensity values are about the same. Nonetheless, the use of INQUA scale is suggested in combination with the existing ones, as an assessing tool of the intensity based only on geological effects
\end{abstract}

Key words: Intensity, Earthquake, INQUA, Greece.

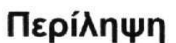

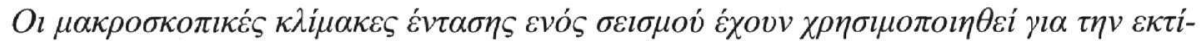

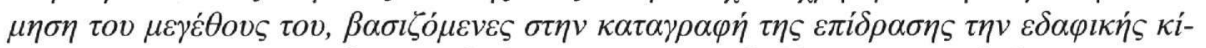

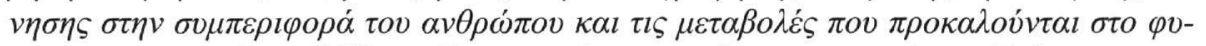

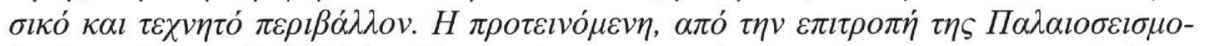

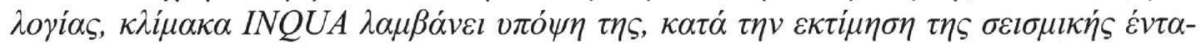

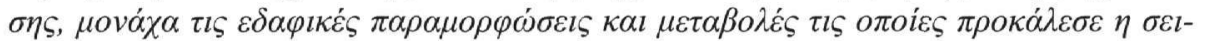

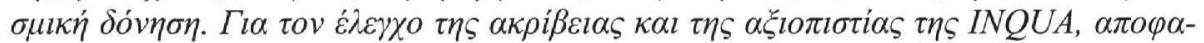

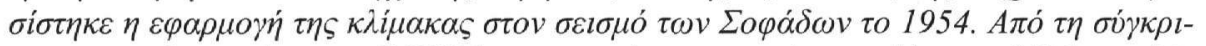

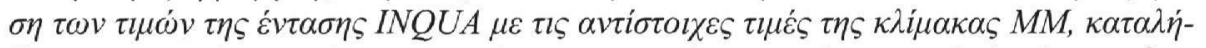

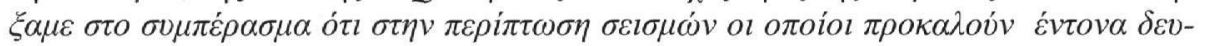

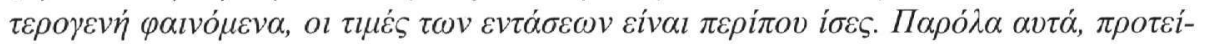

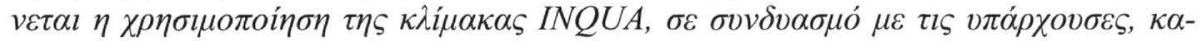

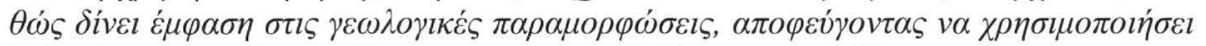

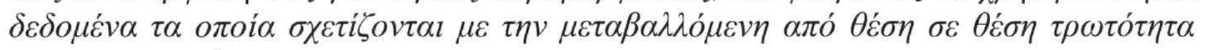
$\tau \omega \nu \kappa \alpha \tau \alpha \sigma \kappa \varepsilon v \omega \dot{v}$.

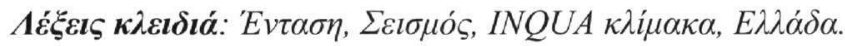




\section{Introduction}

Macroseismic intensity values have been used for the assessment of the seismic hazard of an area since they measure somehow the ground shaking by taking into consideration its impact on humans, structures and the environment. However, the last decade during this assessment there has been an undervaluation of the role of earthquake-induced ground deformation. The new intensity scale, INQUA, is based only on the environmental effects that are triggered by an event.

In order to test its accuracy and reliability, the definitions of intensity degrees of this scale were applied to Sofades 1954 earthquake. Afterwards, the evaluated 'INQUA' intensities are compared with the MM degrees of the earthquake, as they were assessed by Papazachos and Papazachou (1989). Previous tests of the INQUA scale in Greece were performed by Papathanassiou and Pavlides (2006) and Fokaefs \& Papadopoulos (2006) concerning the Lefkada 2003, Elia 1988 and Athens 1999 earthquakes respectively.

\section{Leontari-Anavra Fault Zone and the 1954 earthquake}

\subsection{Geologic setting}

The studied area is situated on the southern part of the Western Thessaly plain, a Late Cainozoic extensional basin (Caputo 1990, Caputo and Pavlides 1993). Western Thessaly basin is filled with Late (?) Pliocene-Holocene fluvio-terrestrial deposits, with a thickness of more than $500 \mathrm{~m}$. The basement and surrounding hills consist of Alpine formations from Pelagonian, Pindos and Koziakas/Western Greece geotectonic units (Aubouin 1959, Kallergis 1970, Caputo 1990), mainly limestones, flysch and ophiolites. Molassic sediments of undetermined age (possibly OligoceneMiocene) are found near Domokos and Anavra (Caputo 1990).

Western Thessaly basin was formed during the first extensional phase (Late Miocene-Pliocene), following or during post-orogenic collapse, trended NE-SW (Merciet et al. 1979, Caputo and Pavlides 1993). The second extension phase, trending N-S, started in Middle Pleistocene and activated E-W and ENE-WSW striking faults.

\subsection{Leontari-Anavra Fault Zone}

Among the Late Quaternary faults bounding the southern part of Western Thessaly Plain, Leontari-Anavra Fault Zone is the dominant active fault zone. Following the 1954 Sofades earthquake surface ruptures, detailed studies revealed information about this previously unknown fault zone (Papastamatiou and Mouyiaris 1986a, Caputo 1990, Papadopoulos 1992, Mountrakis et al. 1993, Goldsworthy and Jackson 2000, Valkaniotis 2005).

Leontari-Anavra Fault Zone consists of four linked segments (Kedros, Leontari, Velesiotes and Thaumako) dipping $\mathrm{N}$, in an en echelon arrangement trending ENE-WSW (Fig. 1). Separate segments have length of 5000 to $7000 \mathrm{~m}$, with a total length of up to $25 \mathrm{~km}$. Continuous activity along the fault zone and basin-ward migration in combination with overlapping segments has led to the creation of a multiple-scarp footwall morphology. Linkage of fault segments is shown by relay ramps and even transfer faults in segment boundaries, leading to overlapping or abandoned fault tips (Valkaniotis 2005).

Leontari-Anavra Fault Zone is responsible for the $30^{\text {th }}$ April 1954 Sofades earthquake, having a magnitude of $\mathrm{Ms}=6.8$ (Papastamatiou and Mouyiaris 1986a, Ambraseys and Jackson 1990, Caputo 1990, Ambraseys and Jackson 1998, Ambraseys 2001). The full length of the fault zone is believed to have been ruptured during the earthquake. Surface ruptures with a mean vertical displacement of about $1 \mathrm{~m}$ were documented along the fault zone, mainly for 2-3 km between Gavrakia and Ekkara (Kato Agoriani) villages (Papastamatiou and Mouyiaris 1986a). However, recent studies report more individual surface ruptures all along the $25 \mathrm{~km}$ fault zone (Ambraseys and Jackson 1990, Pavlides 1993, Valkaniotis 2005). The lack of major documented surface 
ruptures is believed to be a combination of un-sufficient post-earthquake surveys and the possibility of important post-earthquake slip along the fault. Reports for continuous repairs of broken railway lines near Velesiotes fault for more than a week after the earthquake support the latter scenario (Papastamatiou and Mouyiaris 1986a, Valkaniotis 2005).

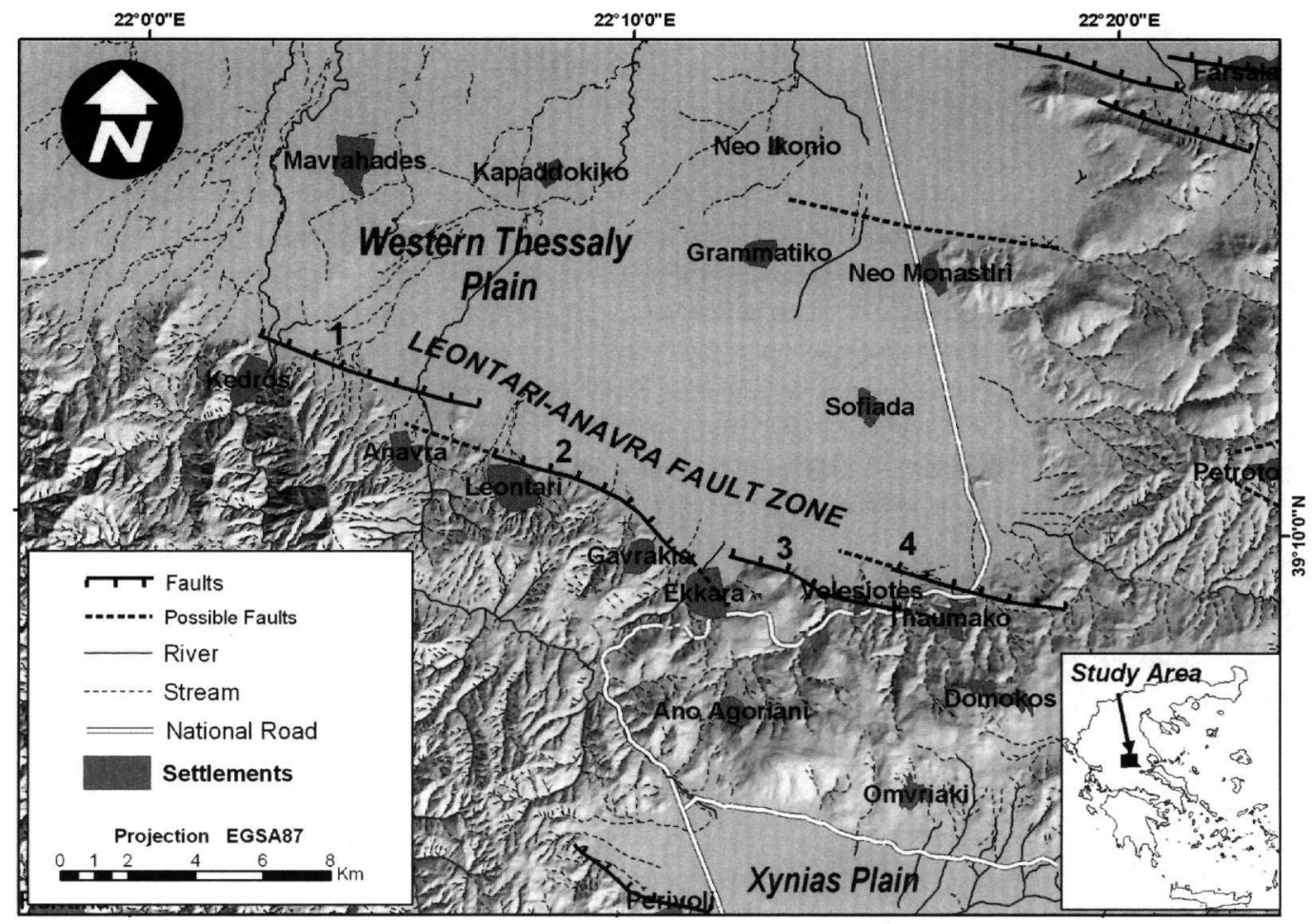

Figure 1 - Active and possible active faults in southern part of Western Thessaly plain.

Leontari-Anavra Fault Zone, ruptured during the 1954 earthquake, consists of four separate segments: Kedros (1), Leontari (2), Velesiotes (3) and Thaumako (4). Shaded relief and drainage network digitized from Hellenic Army Topographic Maps of 1:50.000 scale. Fault data from Valkaniotis (2005)

\section{The Sophades 1954 earthquake}

On April 30th, 1954 an earthquake (Ms 6.8) occurred in Thessaly, Central Greece. According to the Laboratory of Geophysics of the Dept. of Geology, Aristotle University of Thessaloniki its focus was located at $39.3^{\circ} \mathrm{N} 22.2^{\circ} \mathrm{E}$. The maximum intensity based on MM scale was evaluated as IX at the town of Sofades (Papazachos and Papazachou 1989).

This event induced severe damages to the majority of the houses at the large population areas in central Greece. In particularly, 32 and 18 per cent of the building stock, respectively, of the towns of Karditsa and Farsala was destroyed, while in Sofades more than 90 per cent of the houses were collapsed or heavily damaged (Ambraseys and Jackson 1990). Earthquake environmental effects, such as surface faulting and liquefaction-induced ground deformation, were reported in detailed by Papastamatiou and Mouyiaris (1986a) and Ambraseys and Jackson (1990). 


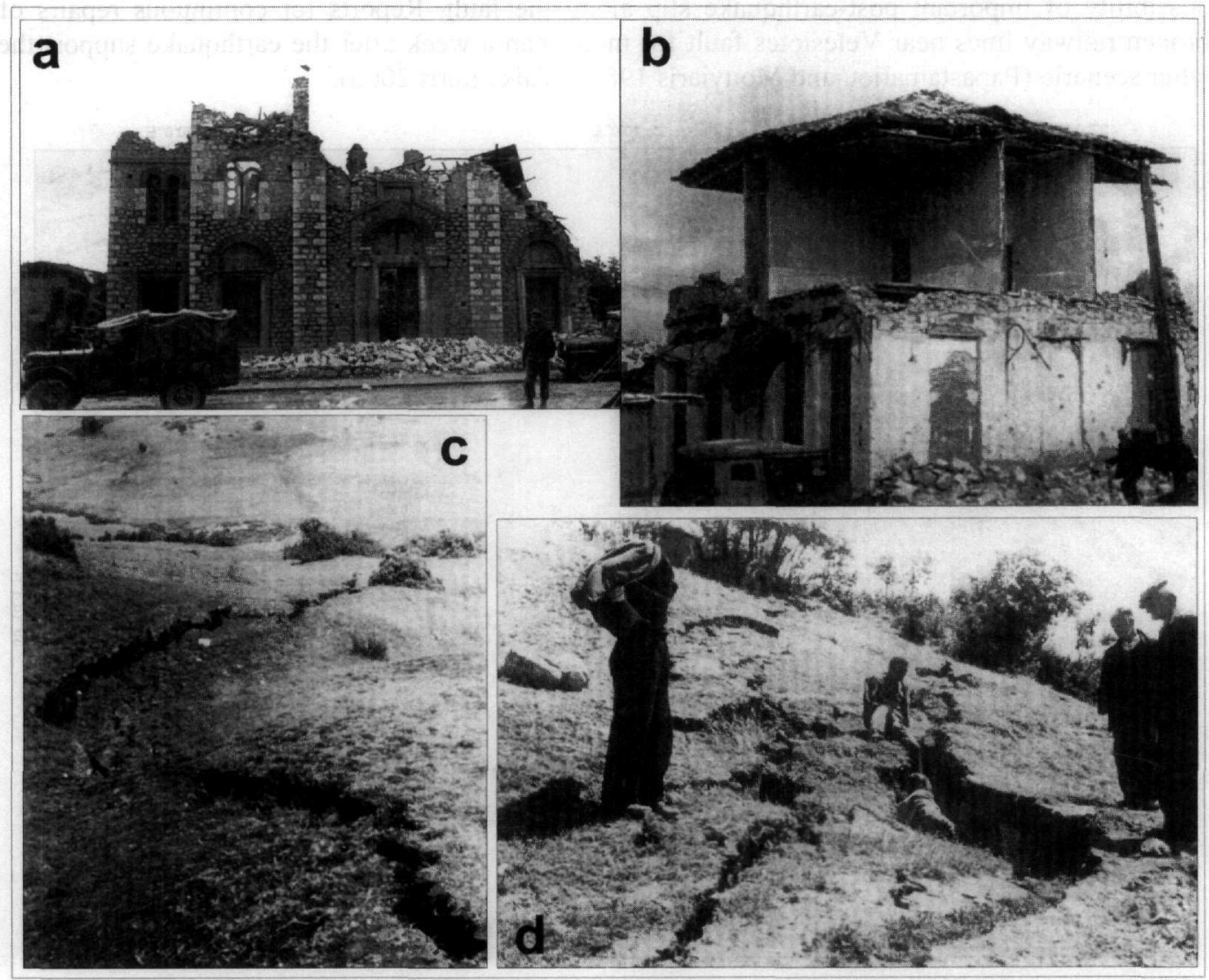

Figure 2 - a,b) Structural damages at Sofades; c,d) surface faulting at the locations of Ekkar a (Kato Agoriani) and Ano Agoriani, respectively (photos from Papastamatiou \& Mouyiaris, 1986b)

\subsection{Evaluation of the intensity degrees based on INQUA scale.}

In order to evaluate the macroseismic intensity, the descriptions of Papastamatiou and Mouyiaris (1986a, 1986b) and Ambraseys and Jackson (1990) were used, while the estimated degrees were assessed based on the definition of INQUA scale (Michetti et al. 2004). The full text of the INQUA intensity degrees can be found on the website http://www.apat.gov.it/site/enGB/Projects/INQUA_scale/

The locations, where the macroseismic intensity was assessed based on INQUA scale, are classified in two categories, depending on the accuracy of the descriptions of the environmental effects. In the first category are classified the sites of Ekkara, Ano Agoriani, Karyes, Agria and Pashalitsa, while the sites of Vouza, Mikro Evidrio, Kipseli and Panagia were listed in the second one. The evaluated intensities for all the locations are listed in Table 1 while their distribution and the isoseismals of VIII and IX are shown in figure 3.

In particular, severe structural damages were observed and appearance of sand was reported in wells at 1-2 $\mathrm{m}$ depth at the coastal part of the village of Agria. This co seismic effect is characterized as modest to appreciable on the environment, according to the definition of INQUA scale "... rare occurrence of significant variations in water levels in wells and variations of chemical-physical properties of water in wells...". Thus, the intensity 'INQUA' degree was evaluated as VI-VII. 
At the location of Ano Agoriani primary effects such as surface faulting of $20 \mathrm{~cm}$ wide and $30 \mathrm{~cm}$ settlement were observed (Fig. 2). These effects leaved significant and permanent traces in the environment, therefore the evaluated INQUA intensity degree is VIII-IX.

Surface faulting was mainly reported at the location of Ekkara (Fig. 2), where the rupture extended for several kilometers, with offsets more than $70 \mathrm{~cm}$, causing damages to the railway line. According to the definition of INQUA scale, this effect is characterized as dominant, thus the evaluated intensity is IX-X, the maximum one for the 1954 earthquake based on INQUA scale.

Table 1 - Evaluated intensity degrees based on INQUA scale

\begin{tabular}{|c|c|c|c|c|}
\hline Site & Latitude & Longitude & $\begin{array}{c}\text { Intensity } \\
\text { (MM scale), by } \\
\text { Papazachos \& Pa- } \\
\text { pazachou, 1989 }\end{array}$ & $\begin{array}{c}\text { Intensity } \\
\text { (INQUA scale) }\end{array}$ \\
\hline Agria & 39.344 & 23.011 & & VI-VII \\
\hline $\begin{array}{c}\text { Ano } \\
\text { Agoriani }\end{array}$ & 39.118 & 22.214 & IX-X & VIII-IX \\
\hline Ekkara & 39.148 & 22.185 & IX-X & IX-X \\
\hline Karyes & 39.084 & 22.417 & & VII \\
\hline Kipseli & 39.368 & 22.139 & VIII-IX & VII \\
\hline $\begin{array}{c}\text { Mikro } \\
\text { Evidrio }\end{array}$ & 39.378 & 22.406 & & VII \\
\hline Panagia & 39.097 & 22.211 & & VII \\
\hline Pashalitsa & 39.356 & 22.193 & IX-X & VIII \\
\hline Velesiotes & 39.150 & 22.249 & & VII-VIII \\
\hline Vouza & 39.157 & 22.362 & & VII \\
\hline
\end{tabular}

Liquefaction phenomena were reported at the locations of Karyes, Vouza, Panagia, Mikro Evidrio and Pashalitsa. In particular at the village of Karyes, ejection of water in a high of 1-2 meters was reported, probably due to the liquefaction of the sublayers, thus according to INQUA scale the intensity value is VII. At the location of Mikro Evidrio, Papastamatiou and Mouyiaris (1986a) reported the ejection of water and sand mixture from ground cracks on the fields, consequently the value of intensity is estimated as VII based on INQUA scale. Similar phenomena, like appearance of water on the fields characterized as liquefaction-induced effects by Ambraseys and Jackson (1990), were reported at the location of Vouzia, assessing a value of VII for the INQUA intensity.

Moreover, at the location of Pashalitsa, a subsidence of $50 \mathrm{~cm}$ was reported and ejection of water with sand was observed at the same area. Furthermore, ground crack of $50 \mathrm{~m}$ length was observed inside the village. According to the definition of INQUA scale, these effects are characterized as considerable "... localized settlements (subsidence up to ca $30 \mathrm{~cm}$ )...liquefaction may be frequent in the area...", thus the evaluated intensity is equal to VIII. At the village of Kipseli, Papastamatiou and Mouyiaris (1986b) reported the appearance of rupture with small wide $(10 \mathrm{~cm})$, while Ambraseys and Jackson (1990) mentioned this site as a liquefaction occurrence area. Therefore, the INQUA intensity is assessed as VII. At the site of Panagia, taking into account the 
activation of a small spring (Papastamatiou and Mouyiaris 1986b), the evaluated INQUA intensity is equal to VII.

Additionally, empirical relations between epicentral intensity (Io) and surface faulting parameters were used for evaluating the degree of Io. According to Michetti et al. (2004) the length of the surface rupture (SRL) and the maximum displacement (MD) are correlated to the epicentral intensity with the following equations:

$$
\begin{aligned}
& I o=0.5503 \times \operatorname{Ln}(S R L)+7.861 \\
& I o=0.5786 \times \operatorname{Ln}(M D)+9.51
\end{aligned}
$$

In our case, the SRL $(\mathrm{km})$ of the causative fault was $25 \mathrm{~km}$ (Ambraseys and Jakson 1998, Valkaniotis 2005), thus using equation [1] the estimated value of epicentral intensity is Io=9.6. The same value is approximately computing based on equation [2], taking into account that the maximum displacement of the 1954 earthquake was 1m (Papastamatiou and Mouyiaris 1986a). The computed degrees of epicentral intensity by equations [1] and [2] are in agreement with the one $(\mathrm{Io}=\mathrm{IX}-\mathrm{X})$ that was evaluated based on the reported earthquake-induce environmental effects of the 1954 shock, using the definitions of INQUA scale.

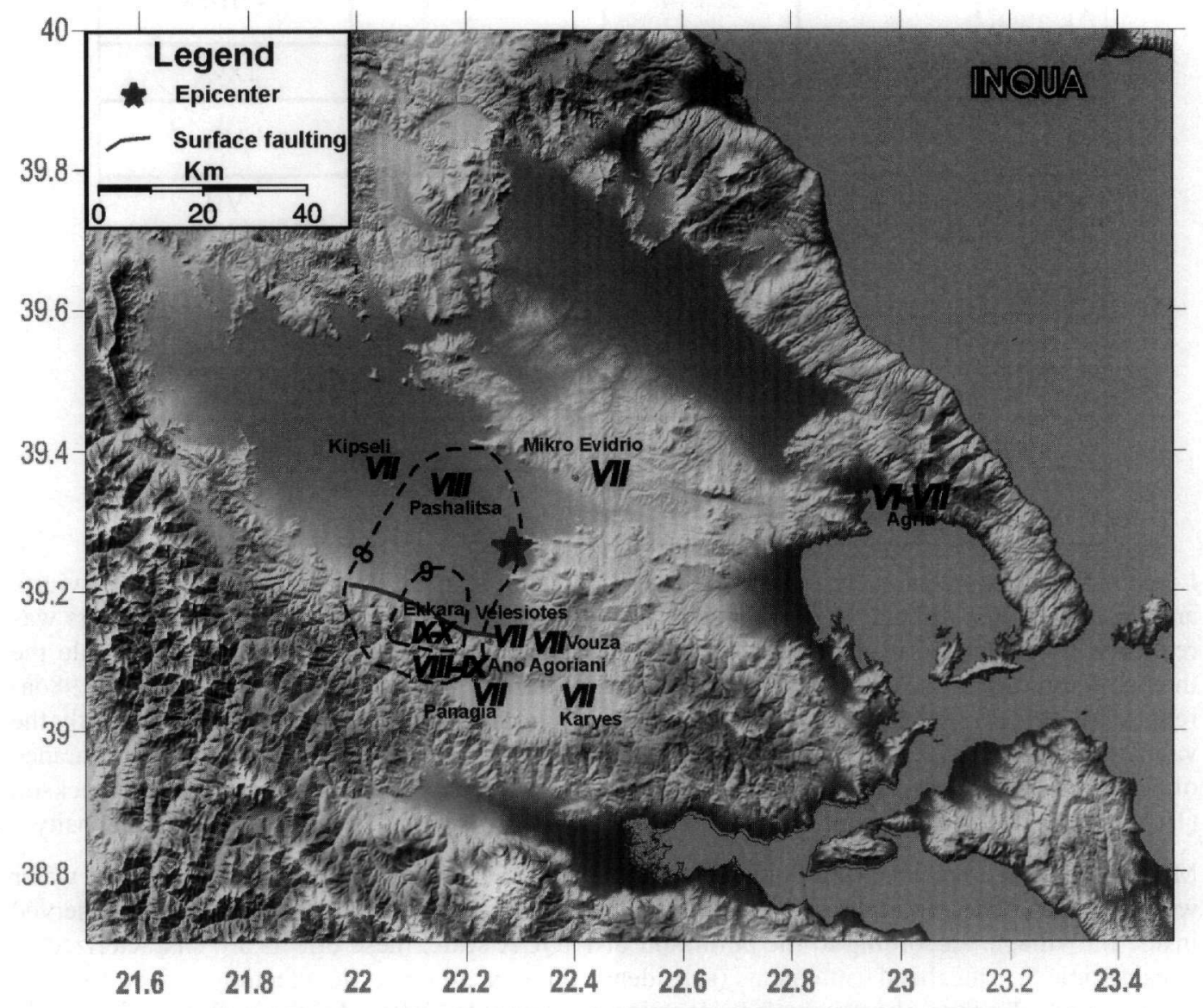

Figure 3 - Distribution of the intensity based on INQUA scale

The macroseismic intensities for these sites based on MM scale were evaluated as: Sofades, Pashalitsa (IX-X), Kipseli (VIII-IX), Ekkara, Ano Agoriani (IX-X) according to Papazachos and Papazachou (1989). From the comparison among the MM scale values with those based on 
INQUA scale, it seems that the degrees of intensity are about the same at the locations where severe environmental effects were triggered by the event. However, the maximum intensity based on MM scale was located, except from the site of Ekkara, at a site called Sofades (Fig. 2) where, as it is mentioned above, 90 per cent of the building stock was destroyed; although no remarkable secondary effects were reported.

\section{Conclusions}

The Sofades 1954 earthquake (Ms 6.8) induced severe structural damages and remarkable environmental effects in an extended area of Central Greece. In order to evaluate the macroseismic intensities, a new scale, INQUA, was applied. The maximum intensity, based on IQNUA scale, was evaluated as IX-X at the site of Ekkara, where surface faulting was reported. At the other locations, the degrees of intensities range from VI to VIII. From the comparison of the "INQUA" values of intensities with the "MM" ones, as they were assessed by Papazachos and Papazachou (1989), is concluding that at sites where the event induced severe secondary effects the evaluated intensities are about the same. However, at the site of Sofades the degree of intensity based on MM scale was evaluated as IX-X due to structural damages, although no ground deformations were reported.

Therefore, we conclude that, in case of earthquakes-induced ground deformations the application of the new macroseismic intensity scale (INQUA) results to the same degrees of intensity as the MM scale. Nonetheless, the use of this new scale is proposed, in combination with the existing scales, since it emphasizes the role of geological effects avoiding taking into account building's performance which differs from site to site.

Moreover, the epicentral intensity (Io) was estimated using empirical relationships which correlate the degree of Io with the surface faulting parameters. The computed intensity degree is in agreement with the value that was assessed using the reported ground deformations.

\section{References}

Ambraseys, N.N., 2001. Reassessment of earthquakes, 1900-1999, in the Eastern Mediterranean and the Middle East, Geophys. J. Int., 145, 471-485.

Ambraseys, N.N., and Jackson, J.A., 1990. Seismicity and associated strain of central Greece between 1890 and 1988, Geophys. J. Int., 101, 663-708.

Ambraseys, N.N., and Jackson, J.A., 1998. Faulting associated with historical and recent earthquakes in the Eastern Mediterranean region, Geophys. J. Int., 133, 390-406.

Aubouin. J., 1959. Contribution a l'etude geologique de la Grece septentrionale: les confines de l'Epire et de la Thessalie, Ann. Geol. Pays Helleniques, 10, 1-525.

Caputo, R., 1990. Geological and structural study of the recent and active brittle deformation of the Neogene - Quaternary basins of Thessaly (Central Greece), PhD Thesis, Aristotle University of Thessaloniki.

Caputo, R., and Pavlides, S., 1993. Late Cainozoic geodynamic evolution of Thessaly and surroundings (central - northern Greece), Tectonophysics, 223, 339-362.

Foakefs, An., and Papadopoulos, G., 2006. Testing the new INQUA intensity scale in Greek earthquakes, Quaternary International, accepted

Goldsworthy, M., and Jackson, J., 2000. Active normal fault evolution in Greece revealed by geomorphology and drainage patterns, Geological Society Journal, 157, 967-981.

Kallergis, G., 1970. Hydrogeologic Investigation of Kalambaka Sub-basin (W.Thessaly), Geol. Geophys. Studies, IGEY, XIV/1, 197p. 
Mercier, J.L., Delibasis, N., Gautier, A., Jarrige, J.J., Lemeille, F., Phillip, H., Sebrier, M., and Sorel, D., 1979. La néotectonique de l'Arc Egeen, Rev. Geol. Dyn. Geogr. Phys., 21, 67-92.

Michetti, A.M., Esposito, E., Gurpinar, A., Mohammadioun, B., Porfido, S., Rogozhin, E., Serva, L., Tatevossian, R., Vittori, E., Audemard, F., Comerci, V., Marco, S., McCalpin, J., and Morner, N.A., 2004. The INQUA scale. An innovative approach for assessing earthquake intensities based on seismically0induced ground effects in natural environment, Memorie descrittive della carta geologica d'Italia, LXVII, 118pp.

Mountrakis, D., Kilias, A., Pavlides, S., Zouros, N., Spyropoulos, N., Tranos, M., and Soulakellis, N., 1993. Field study of the Southern Thessaly highly active fault zone, Proc. 2nd Congr. Hell. Geoph. Union, Florina, May 1993, Greece, vol. 2, 603-614.

Papadopoulos, G.A., 1992. Rupture zones of strong earthquakes in the Thessalia region, Central Greece, Proc. XXIII General Assembly Europ. Seismol. Commis. Prague, September 1992, vol. 2, 337-340.

Papathanassiou, G., and Pavlides S., 2006. Using the INQUA scale for the assessment of intensity: Case study of the 2003 Lefkada (Ionian Islands), Greece earthquake, Quaternary International. accepted

Papastamatiou, D., and Mouyaris, N., 1986. The earthquake of April 30, 1954, in Sophades (Central Greece), Geophys. J.R. Astron. Soc., 87, 885-895.

Papastamatiou, D., and Mouyaris, N., 1986b. The Sophades earthquake occurred on April $30^{\text {th }}$ 1954 - Field observations by Yannis Papastamatiou, Geol. and Geoph. Res., IGME, Athens, 341-362.

Papazachos, B.C., and Papazachou, K., 1989. The earthquakes of Greece, Ziti Publ., Thessaloniki, $365 \mathrm{pp}$.

Pavlides, S., 1993. Active faulting in multi-fractured seismogenic areas: examples from Greece, $Z$. Geomorph. N.F., 94, 57-72.

Valkaniotis, S., 2005. Study of Western Thessaly Active Faults, Unpublished Msc thesis, Aristotle University of Thessaloniki, 145pp. 